\title{
Aerosol connections between three distant continental stations
}

\author{
Jost Heintzenberg $^{\mathrm{a}, *}$, Fabian Senf ${ }^{\mathrm{a}}$, Wolfram Birmili ${ }^{\mathrm{b}}$, Alfred Wiedensohler ${ }^{\mathrm{a}}$ \\ ${ }^{a}$ Leibniz Institute for Tropospheric Research (TROPOS), Permoserstr. 15, 04318, Leipzig, Germany \\ ${ }^{\mathrm{b}}$ German Environment Agency (Umweltbundesamt), Section II 1.3, Corensplatz 1, 14195, Berlin, Germany
}

A R T I C L E I N F O

\section{Keywords:}

Continental aerosol

Particle number size distribution

Long-term measurements

Particle growth

Sub-cloud aerosol particle scavenging

\begin{abstract}
A B S T R A C T
The present study is based on hourly aerosol particle and ancillary data taken at three stations in Northeastern Germany 150-200 km apart in the years 2009 through 2015 in order to investigate systematic process related differences that might show up when connecting their data with forward and backward air mass trajectories. The analysis of changes in the atmospheric aerosol during air mass transport between the stations focused on two low-pollution-to-high-pollution pathways of similar distance around $200 \mathrm{~km}$. Despite rather different initial size distributions the increases in total concentration of particle number, volume, and black carbon agreed within $15 \%$. Systematic variations were found in the different concentration increases as a function of time of day at which an interstation air mass transport took place that could be explained with related source and transport processes.

With Radar-based precipitation data at the stations and along connecting trajectories sub-cloud particle scavenging was investigated. At each station sub-cloud particle scavenging coefficients were determined as a function of particle size between 10 and $700 \mathrm{~nm}$ diameter, and as a function of precipitation sums. Median particle scavenging coefficients taken over the central part of the size range of the study strongly increased between 0.2 and $1 \mathrm{~mm}$ of precipitation and then planed out towards higher precipitation values. With the particle scavenging coefficients determined at the individual stations and precipitation data along connecting trajectories the sub-cloud particle scavenging analysis was extended to wet scavenging along the transport paths yielding median sub-cloud scavenging ratios over the range $0.2-25 \mathrm{~mm}$ of precipitation sums with a non-linear shape similar to that of the median particle scavenging coefficients at the individual stations. Whereas in light precipitation more than $80 \%$ of the initial particles in the considered range survived $150-200 \mathrm{~km}$ of transport, more than $50 \%$ was scavenged by more than $15 \mathrm{~mm}$ of precipitation during aerosol transport.
\end{abstract}

\section{Introduction}

With the advent of automated mobility particle size spectrometers, (e.g., Birmili et al., 1999) stable long-term time series of high resolution sub-micrometer particle number size distributions became possible. First, few individual stations with such instrumentation, (Baltensperger et al., 1997; Birmili et al., 2001; Mäkelä et al., 2000), and later, networks of stations were established, (Asmi et al., 2011; Birmili et al., 2016; Dal Maso et al., 2007; Tunved et al., 2003).

Concurrent measurements at several stations of an aerosol network stimulated the study of spatial variation of the near-surface aerosol, beginning on local scales within cities. Buzorius et al. (1999) studied the variation of aerosol number concentration within Helsinki, Finland. Within Stockholm, Sweden, Johansson et al. (2007) determined spatial distributions of particle number and mass concentrations. Tuch et al. (2006) investigated the correlation of particle number size distributions between two stations $1.5 \mathrm{~km}$ apart in Leipzig, Germany. With the focus on particle nucleation the comparative scale was widened to $50 \mathrm{~km}$ by Wehner et al. (2007). On that scale Lammel et al. (2005) investigated chemical aerosol changes in the urban plume of Berlin, Germany. Within the project Midwest Interstate Sulfur Transformation and Transport (MISTT) the urban aerosol plume of St. Louis, MIS was followed with trajectories to a rural site $104 \mathrm{~km}$ downwind (Ellestad, 1980). On a statistical long-term base aerosol data from a European network of stations were connected with $850 \mathrm{mb}$ trajectories within the project Long Range Transport of Air Pollution (LRTAP) (Eliassen, 1978; Eliassen and Saltbones, 1983; Lemhaus et al., 1986). With state-of-theart aerosol station data and modeling tools the aerosol over Europe was mapped more recently within the project European Integrated project on Aerosol Cloud Climate and Air Quality interactions (EUCAARI), (Kulmala et al., 2011). During the last decades the rapidly growing air pollution of China has stimulated aerosol transport and transformation

\footnotetext{
* Corresponding author.

E-mail address: jost@tropos.de (J. Heintzenberg).
} 
studies in which aerosol data at individual stations were connected with satellite data (e.g., Qin et al., 2016) or mesoscale atmospheric models (e.g., Gao et al., 2014; Jiang et al., 2012; Ye et al., 2016).

The rapidly growing network of sophisticated aerosol stations in Northern European and Baltic countries became the base of numerous studies connecting the stations with air mass history, trajectories, and models. Komppula et al. (2006) combined particle number size distribution measurements and simulations of aerosol dynamics at stations in Finnish Lapland demonstrating the dominance of new particle formation over particle sinks in aerosol moving over $200 \mathrm{~km}$. With oneyear aerosol data at four northern stations Tunved et al. (2005) estimated the aerosol turnover time particle turnover times in air moving from south to north to 1-3 days depending on their size. Analyzing aerosol transport in the opposite direction Tunved et al. (2006b) found the number concentration of particles in the Aitken mode to increase while the mode peak diameter of the number size distribution did not change. Tunved et al. (2006a) determined secondary particle formation over Finnish forest areas by classifying air mass trajectories arriving at rural stations based on their transport time over the boreal forest area. They found that the newly formed particles gradually grew in size during transport in response to biogenic emissions on the way. Väänänen et al. (2013) combined aerosol dynamics and air mass trajectories in an analysis of aerosol data from three stations located within a distance of couple hundred $\mathrm{km}$ at the northern edge of the boreal forest zone. They determined particle growth rates along the transport paths and found that condensational growth can be important in aerosol dynamics even when new particle formation is not evident. Kecorius et al. (2016) investigated increases in aerosol particle number concentrations due to inter-station sources over distances of 490 and $530 \mathrm{~km}$. Vana et al. (2004) speculated about even more than $1000 \mathrm{~km}$ connections of particle nucleation events.

In 2008 the German Ultrafine Aerosol Network, (GUAN), was established to improve the understanding of aerosol processes over Germany (Birmili et al., 2009, 2015; Größ et al., 2018; Nordmann et al., 2009). For the present study we utilized long-term aerosol data taken with hourly time resolution at three GUAN stations in Northeastern Germany $150-200 \mathrm{~km}$ apart. As unique additional information radarderived hourly precipitation rates from the German network of $16 \mathrm{C}$ band weather radars, (Bartels et al., 2004), were added to the aerosol data set at the stations and along hourly forward and backward air mass trajectories connecting the stations. The aim of the study was to understand systematic atmospheric process-related differences, which might occur when connecting the aerosol data with air mass trajectories under different meteorological conditions.

\section{Database}

\subsection{Aerosol in-situ measurements}

Particle number size distributions were determined in the sub-micrometer size range, using TROPOS-custom-made mobility particle size spectrometers (MPSS). The instruments at Waldhof and Neuglobsow had been designed for a diameter range from 10 to $800 \mathrm{~nm}$, whereas in Melpitz a dual MPSS was installed, covering an extended size range from 5 to $800 \mathrm{~nm}$. For the present study the common diameter range $10-800 \mathrm{~nm}$ was utilized. The data acquisition and the yearly calibrations of the instruments followed the recommendations in Wiedensohler et al. (2012) and Wiedensohler et al. (2017), respectively. The temporal resolution of the measurements in Waldhof and Neuglobsow was $5 \mathrm{~min}$ and in Melpitz $20 \mathrm{~min}$. The data inversion was done following the method described by Pfeifer et al. (2014).

Mass concentrations of particulate equivalent black carbon, (BC), were measured at all stations, employing Multi-Angle Absorption Photometers (MAAP- Thermo-Scientific model 5012). The principle of the MAAP had been described in detail in Petzold and Schönlinner (2004). Aerosol particles were collected on a filter, and the light absorption coefficient was determined by radiative transfer considerations, including effects of multiple scattering and absorption enhancement due to light reflection by measuring this parameter at two angles from the filter. The determination of particle light absorption coefficients was based on the transmitted and reflected light components, which were defined by directly measured values of the light transmission, direct and diffuse backscattering. The particle mass concentration of optically equivalent BC was internally calculated, using a constant Mass Absorption Cross-Section of $6.6 \mathrm{~m}^{2} \mathrm{~g}^{-1}$, (Petzold et al., 2013). Temporal resolution of the MAAP was one minute. The performance and inter-comparability of MAAPs had been investigated in Müller et al. (2011) showing a general uncertainty of approximately $10 \%$.

\subsection{Ancillary gas data}

At the station Melpitz, $\mathrm{NO}_{\mathrm{x}}$ was determined with a chemiluminescence instrument (type Horiba APNA 370). For this method, the reaction of nitric oxide $(\mathrm{NO})$ with ozone $\left(\mathrm{O}_{3}\right)$ to excited nitrogen dioxide was utilized. The photons emitted, when leaving the excited state, were counted with a photomultiplier, (NO measurement). To measure also $\mathrm{NO}_{2}$ in the gas stream, the air was passed over a molybdenium catalyst. This procedure yielded NO and NOx, and from the difference the concentration of $\mathrm{NO}_{2}$ was determined.

At the UBA stations Waldhof and Neuglobsow, nitrogen oxides were determined with a nitric oxide analyzer from Thermo Scientific (type: 42i-TL). The measuring method was chemiluminescence with additional photolysis converter. The $\mathrm{NO}_{\mathrm{x}}$ instruments were calibrated on a regular basis, using a certified calibration procedure. The primary temporal resolution of the $\mathrm{NO}_{\mathrm{x}}$ measurements was one minute. Overall measurement uncertainty was considered to be between five and $10 \%$.

\subsection{Trajectories}

Three-dimensional trajectories were calculated arriving and leaving every hour at a height of $500 \mathrm{~m}$ above ground level at the three GUAN stations. The trajectories were calculated forward and backward for up to five days using the HYSPLIT4 model (Draxler and Rolph, 2003) with meteorological data from the Global Data Assimilation System with one-degree resolution (GDAS1). The meteorological fields were downloaded from the server at Air Resources Laboratory (ARL), NOAA (http://ready.arl.noaa.gov), where more information about the GDAS dataset can be found. Aerosol connections between the stations were established by means of the hourly trajectories. Whenever a forward or back trajectory arriving or leaving one station passed another station within $10 \mathrm{~h}$ and a maximum distance of $50 \mathrm{~km}$ the data at the two stations were flagged as connected. On average, the closest distance between trajectory and passed-by station was about $30 \mathrm{~km}$. The number cases, which were flagged as connected depended on the extent of the database at the stations and on the general atmospheric circulation over the region. By utilizing forward and back trajectories each transport direction between a station pair was covered twice. Thus, numbers of connected cases between 1000 and over 10000 during our study period were reached, (see Table 1).

In Fig. 1 the four possible trajectory connections in between two stations (starting at/near A, and ending near/at B) were drawn schematically on the axis "Distance" and "Transport time" between the stations.

Fig. 2 illustrates this approach with 3684 specific hourly forward trajectories from Melpitz to Waldhof in red, and 7501 forward trajectories from Waldhof to Melpitz in blue, ending closer than $50 \mathrm{~km}$ from the other station within $10 \mathrm{~h}$ during 2009-2015. Except for a few outliers that reached the other station on tortuous paths within the given time limit the connecting trajectories covered rather homogeneously a broad corridor between the two stations.

Potential meteorological differences between inter-station aerosol connections were explored with the information "Großwetterlagen", 
Table 1

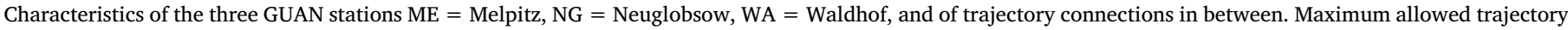

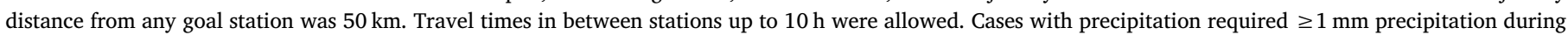
$\geq 3 \mathrm{~h}$ of transport.

\begin{tabular}{|c|c|c|c|c|c|}
\hline ID & Data coverage & $\begin{array}{l}\text { Distance between stations } \\
(\mathrm{km})\end{array}$ & $\begin{array}{l}\text { Average travel time between stations } \\
\text { (h) }\end{array}$ & $\begin{array}{l}\text { Number of trajectory-connected } \\
\text { data }\end{array}$ & Transport cases with precipitation \\
\hline \multirow[t]{2}{*}{ ME } & 2009-01-01 - 2015-12- & ME - NG: 180 & ME to WA: 7.7 & ME to WA: 2411 & ME to WA: 94 \\
\hline & 31 & & ME to NG: 7.9 & ME to NG: 1666 & ME to NG: 170 \\
\hline \multirow[t]{2}{*}{ NG } & 2011-04-18 - 2015-12- & NG - WA: 157 & NG to WA: 5.4 & NG to WA: 1013 & NG to WA: 165 \\
\hline & 31 & & NG to ME: 7.9 & NG to ME: 545 & NG to ME: 150 \\
\hline \multirow[t]{2}{*}{ WA } & 2009-01-01 - 2015-12- & WA-ME: 205 & WA to ME: 7.3 & WA to ME: 3338 & WA to ME: 613 \\
\hline & 31 & & WA to NG: 5.4 & WA to NG: 3211 & WA to NG: 888 \\
\hline
\end{tabular}

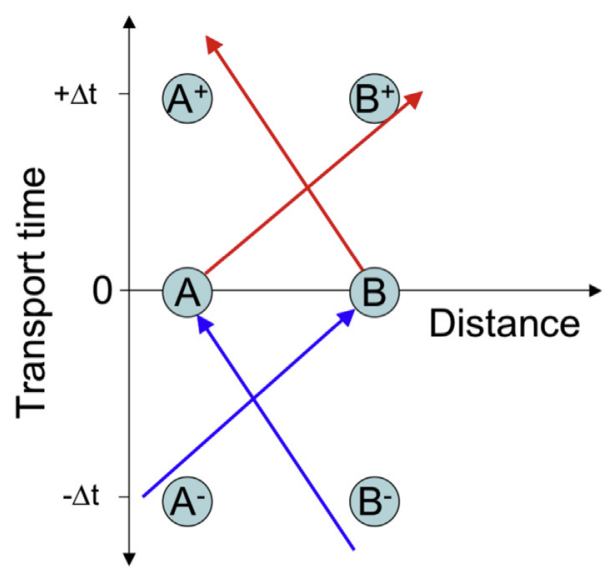

Fig. 1. Schematic presentation of the trajectory connections between two stations, (A, and B), in terms of nominal distance and nominal aerosol transport time $\pm \Delta$ t along trajectories between the stations. Forward trajectories are drawn in red, backward trajectories in blue. $\mathrm{A}^{-}$indicates the station $\mathrm{A}$ at the time $-\Delta t$ before arrival of a backward trajectory at station $B$, i.e., at time $t=0$. $\mathrm{B}^{-}$indicates the station $\mathrm{B}$ at the time $-\Delta$ t before arrival of a backward trajectory starting at station $\mathrm{A} . \mathrm{A}^{+}$indicates station $\mathrm{A}$ at the time $+\Delta \mathrm{t}$ after start of a forward trajectory from station $\mathrm{B}$. $\mathrm{B}^{+}$indicates station $\mathrm{B}$ at the time $+\Delta$ t after start of a forward trajectory from station A. (For interpretation of the references to color in this figure legend, the reader is referred to the Web version of this article.)

(GWL), concerning the 29 large scale weather type classifications after Hess and Brezowsky for Central Europe, (Gerstengarbe and Werner, 1993), provided by the German Weather service for each day (http:// www.dwd.de/DE/leistungen/grosswetterlage/grosswetterlage.html).

During the period of the present study, (and in general), the five most frequent GWL were, (in ranking order), $\mathrm{WZ}=$ Westerlies, mostly cyclonic, TRM $=$ Trough over Central Europe, $\mathrm{BM}=$ High pressure bridge over Central Europe, $\mathrm{SWz}=$ Southwesterlies, mostly cyclonic, and $\mathrm{Wa}=$ Westerlies, mostly anticyclonic.

\subsection{Radar data}

Hourly precipitation estimates were obtained from the RW product of the German Weather Service Radolan composite (Bartels et al., 2004; Weigl and Winterrath, 2009). The product was based on radar-derived hourly precipitation rates from lowest elevation scans of the German network of $16 \mathrm{C}$-band weather radars, at which these scans had been performed every five minutes. The scans were merged and regridded onto a regular $1 \times 1 \mathrm{~km}^{2}$ grid. Hourly radar-based rain rates were estimated from clutter-corrected and quality-assured 5-min radar-reflectivities using a categorized Z-R relationship and aggregation in time. Finally, a weighting technique was applied to adjust the radar-derived hourly precipitation rates to neighboring observations of the German rain gauge network. The detection limit of the RW product was set to $0.1 \mathrm{~mm} / \mathrm{h}$. The RW product had been used successfully previously, e.g.,

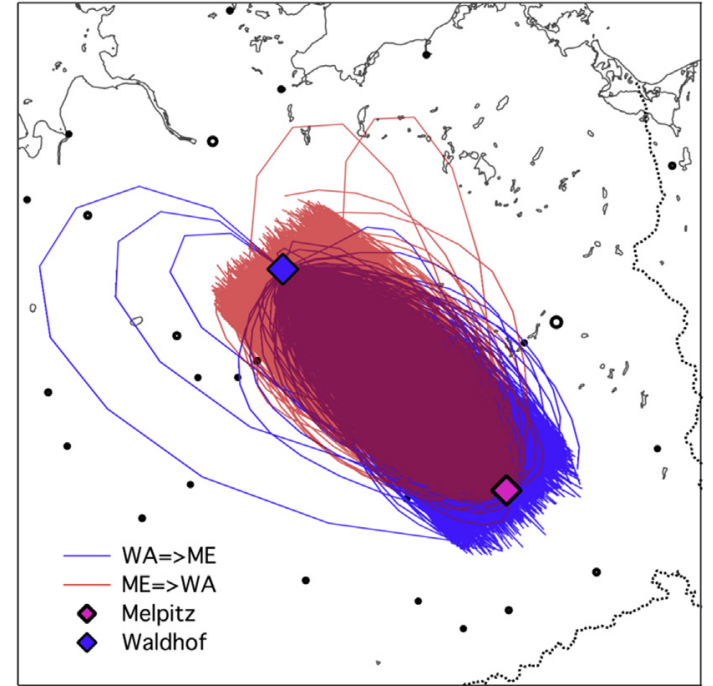

Fig. 2. 3684 hourly forward trajectories during 2009-2015 from Melpitz to Waldhof in red, and 7501 forward trajectories from Waldhof to Melpitz in blue, ending closer than $50 \mathrm{~km}$ from the other station within $10 \mathrm{~h}$ of travel time. The stations are marked with colored diamonds. Cities with populations of 100,000 or larger are shown as black circles on the map with the diameters of the circles being proportional to their population. (For interpretation of the references to color in this figure legend, the reader is referred to the Web version of this article.)

in ensemble precipitation forecasts (Ben Bouallègue and Theis, 2014), and comparisons of different approaches to fit log-normal mixtures on radar-derived precipitation data (Kronenberg et al., 2014). In contrast to local rain gauge observations, the RW product had the advantage to capture the spatial structure and extent of precipitation systems, the effects of which on the atmospheric aerosol were part of the present study. Finally, the Radolan RW product was interpolated to the station locations and to trajectory positions taking the closest corresponding RW grid value.

\section{Results and discussion}

\subsection{Inter-station aerosol comparison}

The most basic way of considering aerosol changes after air mass transport between two stations concerns changes in total number, ( $\triangle \mathrm{NTO}$ ), or total volume, $(\Delta \mathrm{VTO})$. Due to widely varying aerosol and transport conditions the probability distribution functions, (pdf), of $\triangle$ NTO along the six transport cases cover a wide range from decreases of more than $5000 \mathrm{~cm}^{3}$ to increases of the same order of magnitude, (see Fig. 3).

A first comparison of these pdfs and dry average PNSDs at trajectory-connected stations, (see Fig. 4), yielded some insight into pollution changes and aerosol processes along the related pathways. We 


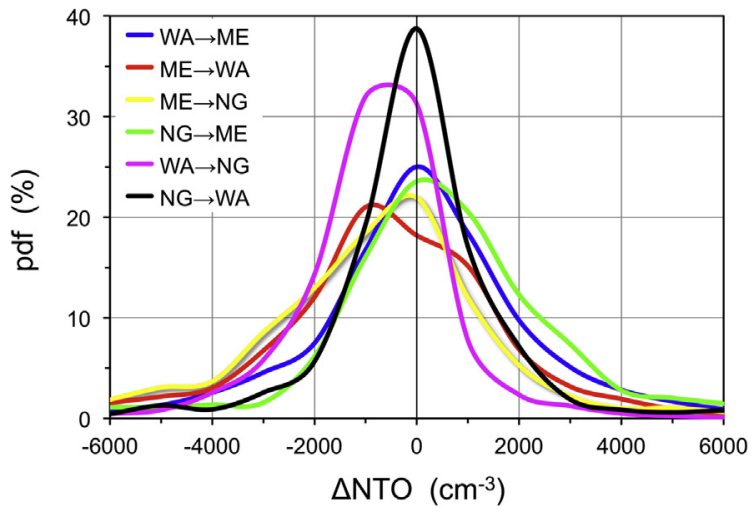

Fig. 3. Probability density functions, (pdf, \%), of changes in total number concentration, $\left(\triangle \mathrm{NTO}, \mathrm{cm}^{-3}\right)$, after air mass transport along the six different paths: WA $\rightarrow$ ME, Melpitz to Waldhof: ME $\rightarrow$ WA, Neuglobsow to Melpitz: NG $\rightarrow$ ME, Melpitz to Neuglobsow: ME $\rightarrow$ NG, Waldhof to Neuglobsow, WA $\rightarrow$ NG, and Neuglobsow to Waldhof: NG $\rightarrow$ WA.

distinguished three regimes of transformations along the connected paths:

Regime 1. Low pollution to high pollution, (WA $\rightarrow \mathrm{ME}, \mathrm{NG} \rightarrow \mathrm{ME}$ ), Regime 2. High pollution to low pollution, (ME $\rightarrow$ WA, ME $\rightarrow$ NG), Regime 3. Low pollution to low pollution, (WA $\rightarrow$ NG, NG $\rightarrow$ WA).

The low-pollution-to-high-pollution regime one was characterized by an increase in particle number concentrations over a broad range from about $30 \mathrm{~nm}$ to the upper size limit of the study. Below the lower limit of $\approx 30 \mathrm{~nm}$ both concentration decreases, (WA $\rightarrow \mathrm{ME}$ ), and increases, (NG $\rightarrow \mathrm{ME}$ ), did occur. Air mass transport in opposite directions occurred in the high-pollution-to-low-pollution regime two, which was characterized by nearly constant PNSDs above about $100 \mathrm{~nm}$ and substantial losses of particles below that diameter. At a lower pollution level the transport WA $\rightarrow$ NG showed the latter loss/gain situation even clearer, (cf. bottom panels in Fig. 4), whereas transport in the opposite direction, (NG $\rightarrow$ WA) on average showed no significant changes in PNSDs over $\approx 160 \mathrm{~km}$ of transport distance. In following sections systematic aerosol changes in between the stations will be explored.

\subsection{Inter-station aerosol processes}

The complete description of aerosol transformations along an atmospheric trajectory on the time scale of ten hours requires the use of a complex chemical/physical aerosol dynamics model such as presented by Tunved et al. (2010). The formulation and/or application of such a complex model was beyond the scope of the present study. Instead, we focused our analyses on the discussion of cases and processes, which we could hope to be able to describe with simple transformation models, such as inter-station aerosol particle formation, and sub-cloud wet scavenging. There were several factors with which to choose from the six possible transport cases in between the three stations: One, logistics, i.e., the available number of connections in between a pair of stations, (cf. Table 1), two, the apparent changes in PNSD between the stations, (cf. Fig. 4), and three, the meteorological conditions during inter-station transport, (cf. Table 1). We excluded from detailed analyses all cases in regime two because they involved substantial small particle losses during dry conditions that would require complex aerosol dynamics for their description, i.e., ME $\rightarrow$ WA, and ME $\rightarrow$ NG. With the same argument we also excluded case WA $\rightarrow$ NG. Our interest in sub-

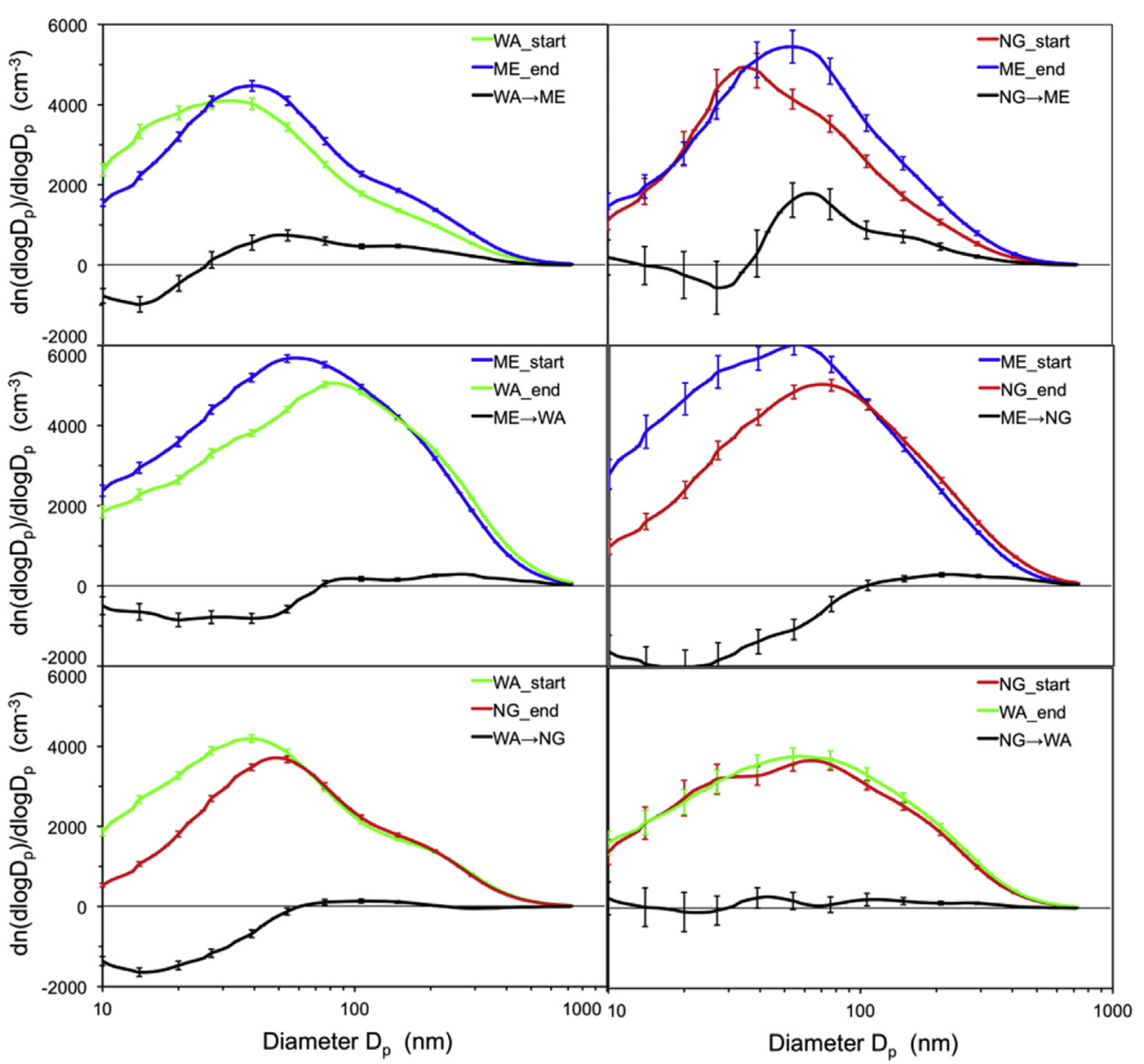

Fig. 4. Particle number size distributions averaged over all hours with connected trajectories without precipitation along the transport path. The depicted transport pathways are Waldhof, (green) to Melpitz, (blue): WA $\rightarrow$ ME, Melpitz to Waldhof: ME $\rightarrow$ WA, Neuglobsow, (red) to Melpitz: NG $\rightarrow$ ME, Melpitz to Neuglobsow: ME $\rightarrow$ NG, Waldhof to Neuglobsow, WA $\rightarrow$ NG, and Neuglobsow to Waldhof: NG $\rightarrow$ WA. The average difference of the respective two size distributions is drawn in black. Error bars indicate two standard deviations about the means. (For interpretation of the references to color in this figure legend, the reader is referred to the Web version of this article.) 
cloud aerosol scavenging corroborated our argument against focusing on regime two because it would have been difficult to distinguish subcloud scavenging from other strong loss processes in these cases. Additionally, meteorology argued against utilizing the cases in regime two for wet scavenging analyses because they predominantly occurred in flow situations with high-pressure systems over Eastern Europe or Scandinavia entailing small chances of precipitation. With the latter argument we also excluded case NG $\rightarrow$ WA.

Before we analyzed specific transport cases we addressed the question: How meaningful is a comparison of aerosol data at station B with corresponding data at station A taken before a calculated trajectory connection between the two stations? In other words, are the apparent aerosol particle changes due to processes along the transport path or are they due to common aerosol changes on scales comparable or larger than the distance between the stations? To explore this issue we compared integral particle properties at the individual stations after transport time $\Delta \mathrm{t}$ with the respective aerosol properties before $\Delta \mathrm{t}$, (cf. Fig. 1 for the definition of $\Delta \mathrm{t}$ ). For this test and for the subsequent growth results in section 3.3.1 we limited the analysis to transport cases with non-negative $\Delta \mathrm{VTO}$ along the transport path, i.e., $\mathrm{VTO}(\mathrm{B}(\mathrm{t}+\Delta \mathrm{t}))$ $\operatorname{VTO}(\mathrm{A}(\mathrm{t}))$. The results are collected in Fig. 5.

In both investigated transport cases, (WA $\rightarrow$ ME, and NG $\rightarrow \mathrm{ME}$ ), average increases in total number, $(\Delta \mathrm{NTO})$, and total volume, $(\Delta \mathrm{VTO})$, were far higher when comparing station $\mathrm{B}$ after transport to station $\mathrm{A}$ before transport than corresponding changes at the individual stations, e.g., $\mathrm{A}^{+\Delta \mathrm{t}}-\mathrm{A}$ or $\mathrm{B}-\mathrm{B}^{-\Delta \mathrm{t}}$. Even for $\Delta \mathrm{BC}$ this comparison yielded the highest average values after transport from station $B$ to station $A$, albeit within two standard deviations of the average value. We note, however, that on average, except for $\triangle \mathrm{NTO}$ at station WA temporal changes were positive at the individual stations during the transport events, indicating that the atmospheric conditions at the stations were conducive to aerosol increases. We took these comparisons of temporal and interstation changes as strong argument for interpreting the differences between station B and station A after transport A $\rightarrow$ B as aerosol increases along the transport path and not as general aerosol changes on scales of distance between A and B or larger and proceed to quantifying the transport related increases in particulate matter in the following section.

\subsubsection{Increase in aerosol particles in regime one (low pollution to high} pollution)

For the study of aerosol particle increase from low to high pollution sites we had the connected data sets from two pairs of stations available: Waldhof to Melpitz, (WA $\rightarrow$ ME), and Neuglobsow to Melpitz, (NG $\rightarrow \mathrm{ME}$ ). Here particle increases are quantified in terms increases in $\triangle \mathrm{NTO}$, and $\triangle \mathrm{VTO}$, (see Table 2).

Prior to a detailed case analysis we addressed the two questions: When do events with apparently connected flows occur and at what times were the strongest aerosol increases recorded? For both transport paths the event counts per month show a broad maximum from March through August with a peak in June, (not shown). In terms of maxima in
$\Delta \mathrm{NTO}$, and $\triangle \mathrm{VTO}$ the two paths differ. Whereas the path WA $\rightarrow$ ME exhibits a clear maximum in both parameters in April with a substantial secondary maximum in $\Delta$ NTO in September, $\Delta$ VTO on the path NG $\rightarrow$ ME peaks already in February with secondary peaks in June and November while $\triangle$ NTO has its main peak in June and a broad secondary maximum during winter, (November through February).

We explored the typical weather conditions of apparently connected flows paired with aerosol increases with the related GWL data. The "Grosswetterlagen" TRM and BM have high frequencies of occurrence on both paths with TRM standing for a trough over Western Europe directing polar air masses to the stations, and BM standing for a highpressure bridge over Europe, over the eastern flank of which, again, polar air is directed to the stations. Highest occurrence for the path WA $\rightarrow$ ME was recorded with GWL system NWA with a strong frontal zone in the direction NW to SE. For the path NG $\rightarrow$ ME the most frequent GWL system was NA, i.e., strong northerly airflow caused by a blocking anticyclone over Western Europe.

When we excluded all cases $\Delta \mathrm{VTO}<0$, and with precipitation at any of the stations and in between 2312 connected hours remained for the pair WA $\rightarrow \mathrm{ME}$, and $403 \mathrm{~h}$ for the pair NG $\rightarrow$ ME. It is remarkable that both, $\triangle \mathrm{NTO}$, and $\triangle \mathrm{VTO}$ along the two very different paths, (NG $\rightarrow$ $\mathrm{ME}$ and WA $\rightarrow \mathrm{ME}$ ), with very different starting PNSDs, (cf. Fig. 5), but with similar length lead to increases in particle number and volume that differed by no more than $\approx 15 \%$.

Two logarithmic normal distributions were added to the average PNSD of the constrained data at station A to simulate the aerosol increase on the way from station A to station B. With Microsoft Excel's nonlinear Generalized Reduced Gradients, (GRG), solver the parameters of these two normal distributions were optimized in order to yield minimum average relative deviations of $12-17 \%$ between the modified PNSD at station A and that at station B. The parameters of the derived lognormal distributions quantifying the average aerosol particle growth on the two low-to-high-pollution paths NG $\rightarrow$ ME, and WA $\rightarrow$ ME were collected in Table 2. The parameters of the two lognormal additions indicated that both Aitken, (below $80 \mathrm{~nm}$ ), and accumulation mode, $(\geq 100 \mathrm{~nm})$, particles were added to the initial distributions. Average PNSDs at start and end of the events are shown in Fig. 6 together with the starting PNSDs to which the two optimum lognormal distributions were added.

The latter simulations of the aerosol at the end of the transport paths showed that on both paths not only aerosol increases were recorded. Below $\approx 40 \mathrm{~nm}$ particle diameter losses occurred during aerosol transport to Melpitz. These apparent losses may reflect particle growth through coagulation, condensation or liquid phase reactions. It is remarkable, though that, despite different pathways, initial and final aerosol, (cf. Fig. 6), comparable particulate number, volume and black carbon were gained during aerosol transport from Waldhof and Neuglobsow to Melpitz.

So far we considered aerosol particle changes averaged over months to years. Several factors can cause considerable diurnal variations in aerosol particle changes during transport between stations. Traffic and

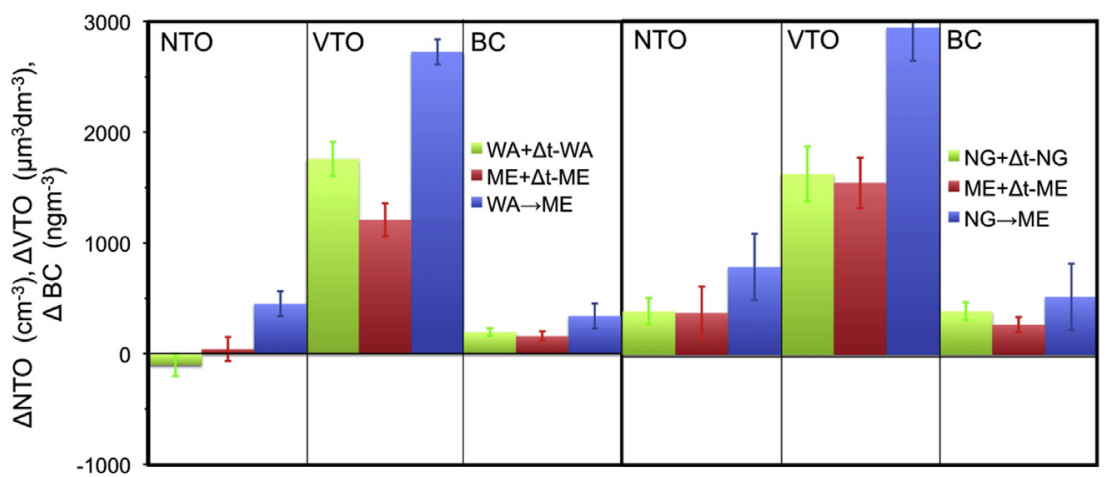

Fig. 5. Average changes of total number, $\left(\Delta \mathrm{NTO}, \mathrm{cm}^{-3}\right)$, total volume, $\left(\Delta \mathrm{VTO}, \mu \mathrm{m}^{3} \mathrm{dm}^{-3}\right)$, and Black Carbon, $(\Delta \mathrm{BC}$, $\mathrm{ngm}^{-3}$ ), during conditions of dry transport with $\triangle \mathrm{VTO} \geq 0$ at the stations WA, NG, and ME, compared to corresponding inter-station changes during transport NG $\rightarrow \mathrm{ME}$, and WA $\rightarrow$ ME. Error bars show two standard deviations of the mean values. 
Table 2

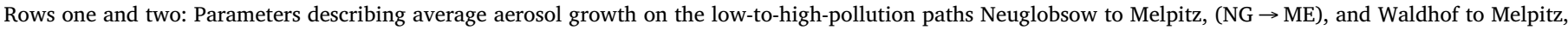

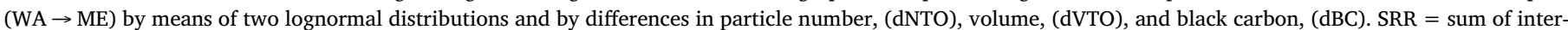

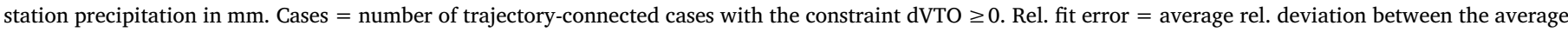

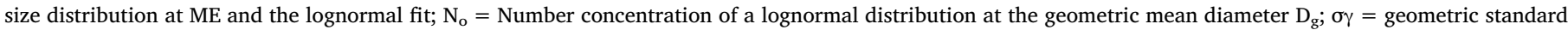

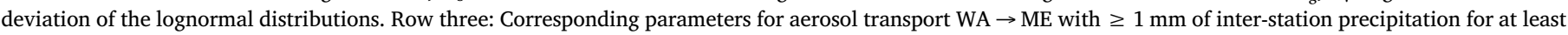
three hours.

\begin{tabular}{|c|c|c|c|c|c|c|c|c|c|}
\hline Path & SRR mm & Cases & Rel. fit error, \% & $\mathrm{N}_{\mathrm{o}}, \mathrm{cm}^{-3}$ & $\mathrm{D}_{\mathrm{g}}, \mathrm{nm}$ & $\sigma_{g}$ & $\mathrm{dNTO} \mathrm{cm}^{-3}$ & dVTO $\mu \mathrm{m}^{3} \mathrm{~cm}^{-3}$ & $\mathrm{dBC}, \mu \mathrm{gm}^{-3}$ \\
\hline \multirow[t]{2}{*}{$\mathrm{NG} \rightarrow \mathrm{ME}$} & 0 & 403 & 12 & 701 & 65 & 1.3 & 790 & 2.9 & .52 \\
\hline & & & & 593 & 141 & 1.7 & & & \\
\hline \multirow[t]{2}{*}{$\mathrm{WA} \rightarrow \mathrm{ME}$} & 0 & 2312 & 17 & 605 & 65 & 1.5 & 450 & 2.7 & .34 \\
\hline & & & & 285 & 197 & 1.6 & & & \\
\hline \multirow[t]{2}{*}{$\mathrm{WA} \rightarrow \mathrm{ME}$} & $\geq 1$ & 613 & 3 & 1120 & 31 & 2.6 & -275 & 0.3 & 0.03 \\
\hline & $\geq 3 \mathrm{~h}$ & & & 232 & 184 & 1.6 & & & \\
\hline
\end{tabular}

energy-related emissions will change during a day as well as the photochemical production of particle precursors and their condensation, transport pathway, and ventilation of the planetary boundary layer. For the low-to-high-pollution station pair WA $\rightarrow$ ME with the largest number of cases we display median aerosol particle changes for nonprecipitation conditions as a function of local time of day at the start of connecting air mass transport in Fig. 7.

Changes in particle concentration below $26 \mathrm{~nm},(\Delta \mathrm{N} 26)$, exhibit the largest diurnal variation spanning a factor of 3.9 of the daily average, with their maximum value for transports starting around 06:00 and their minimum for transports starting around 18:00 local time. Second largest variations occurred in total volume, $\Delta \mathrm{VTO}$, covering a factor of 2.2 of its daily average, albeit with a phase shift of nearly $12 \mathrm{~h}$ as compared to $\Delta \mathrm{N} 26$. We interpreted the maximum of growth in particulate volume during nocturnal aerosol transport as being caused by condensation of particle precursors that had been produced during the day. We suspected that the rather small diurnal variation in the change of total number, i.e., a factor of 0.9 of the daily average, was both a consequence of new particle formation, as indicated by $\Delta \mathrm{N} 26$, and ventilation of the planetary boundary layer. The latter process would also affect the daily changes covering a factor of two of its daily average, of the combustion related black carbon, $(\Delta \mathrm{BC})$.

\subsubsection{Decrease particles in regime one (low pollution to high pollution)}

Wet scavenging of atmospheric particles is a subject of intense ongoing research. The analysis of long time series of PNSDs taken at aerosol observatories, combined with environmental data, can contribute to the understanding of particle scavenging, in particular, subcloud wet scavenging, (e.g., Laakso et al., 2003). Our analysis began with the evaluation of precipitation events at the three stations. With the results at the individual stations we proceeded to the discussion of

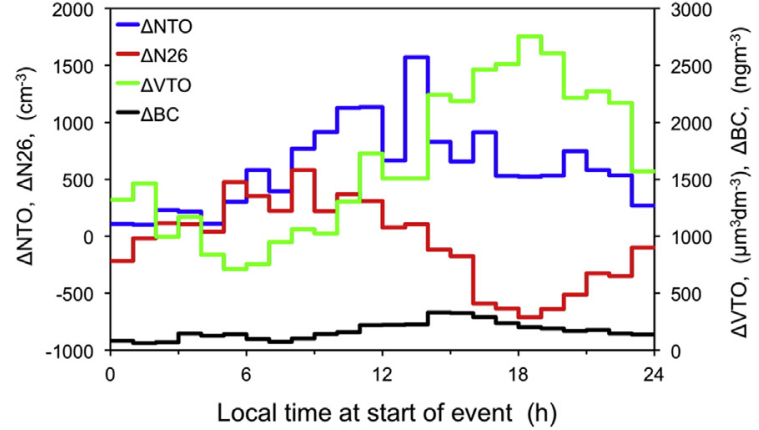

Fig. 7. Median changes in total number concentration, $\left(\Delta \mathrm{NTO}, \mathrm{cm}^{-3}\right)$, number concentration below $26 \mathrm{~nm}$ particle diameter, $\left(\Delta \mathrm{N} 26, \mathrm{~cm}^{-3}\right)$, total volume, $\left(\Delta \mathrm{VTO}, \mu \mathrm{m}^{3} \mathrm{dm}^{-3}\right)$, and black carbon, $\left(\Delta \mathrm{BC}, \mathrm{ng}^{3} \mathrm{~m}^{-3}\right)$, along the transport path WA $\rightarrow$ ME of 2312 events with $\Delta \mathrm{VTO} \geq 0$ as a function of the time of day at which the event started.

the effects precipitation occurring on the transport paths in between the stations.

3.2.2.1. Scavenging at individual stations. In the present study we identified sub-cloud scavenging events by requiring an amount of precipitation $>0.2 \mathrm{~mm}$ per event with event lengths between three and $24 \mathrm{~h}$. With these constraints we identified a total of 960 scavenging events in the time series at the three stations. The median length of the events was four hours, and median precipitation per event about $3 \mathrm{~mm}$. The probability distribution function, (pdf), of the precipitation amount per event in Fig. 8 looked very similar at all three stations. Traditionally, scavenging coefficients $\Lambda,\left(\mathrm{s}^{-1}\right)$, are derived by assuming the scavenging to be proportional to both the length of the

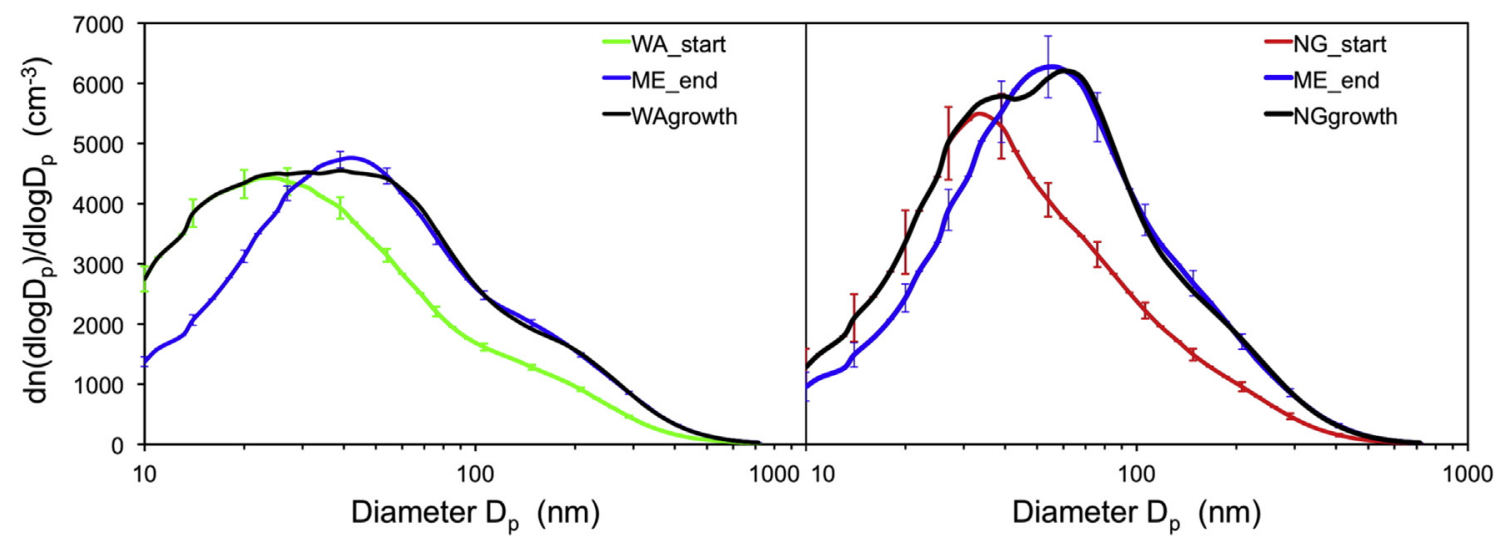

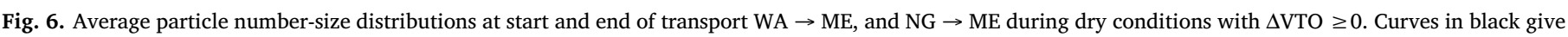

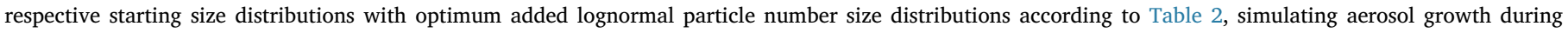
transport. Error bars show two standard deviations of the mean values. 


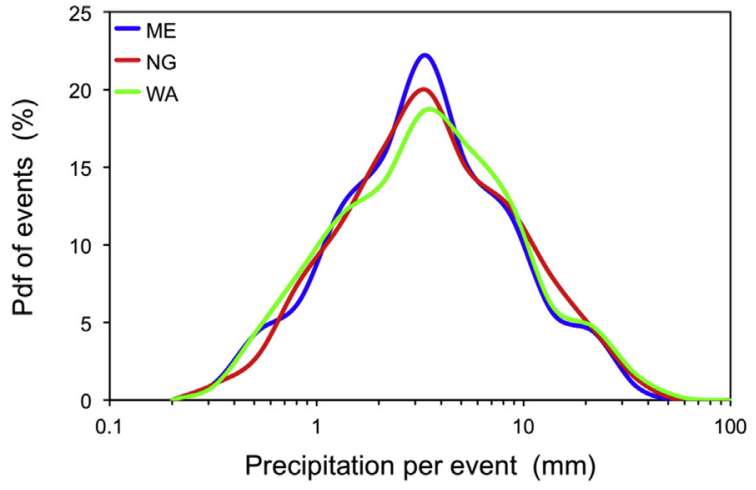

Fig. 8. Probability distribution function, (pdf, \%), of precipitation events as function of the precipitation per event, $(\mathrm{mm})$, at the three GUAN stations Melpitz, (ME, blue), Neuglobsow, (NG, red), and Waldhof, (WA, green). (For interpretation of the references to color in this figure legend, the reader is referred to the Web version of this article.)

event and to the amount (number or mass) of the scavenged material, (Hales et al., 1988).

During precipitation events of several hours certain air mass changes are inevitable, which may affect any scavenging conclusions. As a rough means of compensating for changes in the input aerosol during events we utilized a measured air pollutant that we assumed to be unaffected by sub-cloud scavenging. $\mathrm{NO}_{\mathrm{x}}$ is measured at all three stations and has very low Henry's law constant for water as solvent, (Sander, 2015). Thus, we used the ratio of average $\mathrm{NO}_{\mathrm{x}}$ concentrations during the pre-event periods to average $\mathrm{NO}_{\mathrm{x}}$-concentrations during the events to compensate for aerosol changes caused by varying air mass.

Before we discuss size dependent scavenging we present in Fig. 9 sub-cloud scavenging coefficients for the integral particle properties total number (NTO, $\mathrm{cm}^{-3}$ ), total volume, (VTO, $\mu \mathrm{m}^{3} \mathrm{dm}^{-3}$ ), PM10 mass concentration, and black carbon, $\left(\mathrm{BC}, \mathrm{ngm}^{-3}\right)$. Within $20 \%$ the scavenging coefficients of the three parameters agreed.

The ranking order of scavenging of NTO, VTO, and PM10 at all stations is the same, with NTO exhibiting lowest and PM10 the highest sub-cloud scavenging. The highest scavenging of PM10 we explained by this parameter encompassing mass contributions beyond the upper size limit of the MPSS, $(800 \mathrm{~nm})$, for which models predict steeply rising scavenging coefficients, (Slinn, 1977; Volken and Schumann, 1993). BC lies in between number and volume scavenging. The result for $\mathrm{BC}$ was somewhat counter-intuitive because one might expect $\mathrm{BC}$ to be

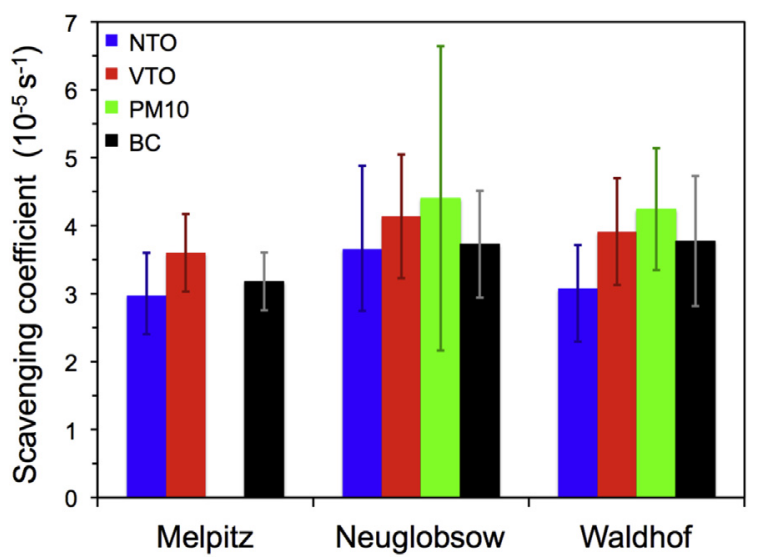

Fig. 9. Sub-cloud scavenging coefficients, $\left(10^{-5} \mathrm{~s}^{-1}\right)$, of total number, (NTO), total volume, (VTO), Particulate mass $<10 \mu \mathrm{m}$ particle diameter, (PM10), and black carbon, (BC), averaged over all precipitation events at the three GUAN stations Melpitz, Neuglobsow, and Waldhof. The error bars give \pm 1 standard deviation of the mean values. PM10 was only available at Neuglobsow and Waldhof.

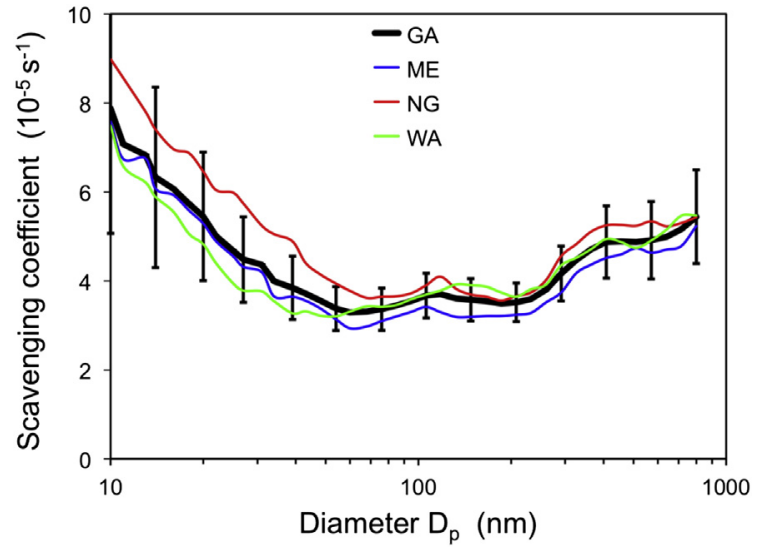

Fig. 10. Average size-dependent sub-cloud scavenging coefficients, $\left(10^{-5} \mathrm{~s}^{-1}\right)$, at the three GUAN stations Melpitz, (ME, blue), Neuglobsow, (NG, red), and Waldhof, (WA, green). The grand average over all stations, (GA), is drawn in black. The error bars give \pm 1 standard deviation of the mean values. (For interpretation of the references to color in this figure legend, the reader is referred to the Web version of this article.)

scavenged less because of its (initially) hydrophobic character, (e.g., Covert and Heintzenberg, 1984; Hallberg et al., 1994). However, averaged over all events and stations $\Lambda_{\mathrm{BC}}=3.5 \cdot 10^{-5} \mathrm{~s}^{-1}$, which is more than twice as high as the value of $1.64 \cdot 10^{-5} \mathrm{~s}^{-1}$, reported by Latha et al. (2005) for urban conditions in Hyderabad, India. BC-concentrations at the GUAN-stations ranged between the detection limit of the MAAP (Petzold et al., 2002, $\approx 100 \mathrm{ngm}^{-3}$ ), and $20 \mu \mathrm{gm}^{-3}$ with a median value around $500 \mathrm{ngm}^{-3}$. Latha et al. (2005) reported a range of $4-88 \mu \mathrm{gm}^{-3}$ for their BC-concentrations. We speculated that the BC in the non-urban environment of the three GUAN-stations may have been somewhat aged and less hydrophobic compared to that in an urban source region such as Hyderabad.

General shape and absolute values of the size-dependent sub-cloud scavenging coefficients in Fig. 10 are similar to the results given by Laakso et al. (2003) for six years of data taken at the Finnish background station Hyytiälä. Their size range of $\approx 20$ to $\approx 500 \mathrm{~nm}$ was somewhat smaller than that of the present study.

Depending to some extent on rain intensity their results scatter by more than a factor of five and show increasing scavenging coefficients below a minimum around $200 \mathrm{~nm}$, and a less steep increase towards larger sizes, which qualitatively agrees with other results, (Slinn, 1977; Volken and Schumann, 1993). However, others did not report the consistent structure that our results show at all three stations with local minima in scavenging around 60 and $200 \mathrm{~nm}$, and a weak local maximum around $120 \mathrm{~nm}$. Excepting identical instrumental problems at all stations, we can only speculate about reasons for the structure in our size-dependent scavenging results. They might have been affected by the modal structure of the PNSDs and by systematic differences in the physico-chemical properties of the different modes of the distribution.

Laakso et al. (2003) found a rather strong dependency of their median scavenging coefficient, $\Lambda_{\text {median }}$, over the range $20-510 \mathrm{~nm}$ on the rain rate, with a factor of two or more increase of $\Lambda_{\text {median }}$ from 0.5 to $\approx 4 \mathrm{mmh}^{-1}$. In Fig. 11 we show $\Lambda_{\text {median }}$, over the range $10-800 \mathrm{~nm}$ of the present study taken over all three stations, which indicated a somewhat smaller dependency of sub-cloud scavenging on rain rate. With the rain rate increasing from 0.5 to $\approx 4 \mathrm{mmh}^{-1} \Lambda_{\text {median }}$ increased only by a factor of 1.4 , albeit starting at a higher level of scavenging than in the Finnish study.

3.2.2.2. Inter-station scavenging. Precipitation along trajectories connecting the three GUAN stations was utilized to study potential aerosol particle scavenging during aerosol transport on a scale of $200 \mathrm{~km}$. Most suitable for this study is the path WA $\rightarrow$ NG because 


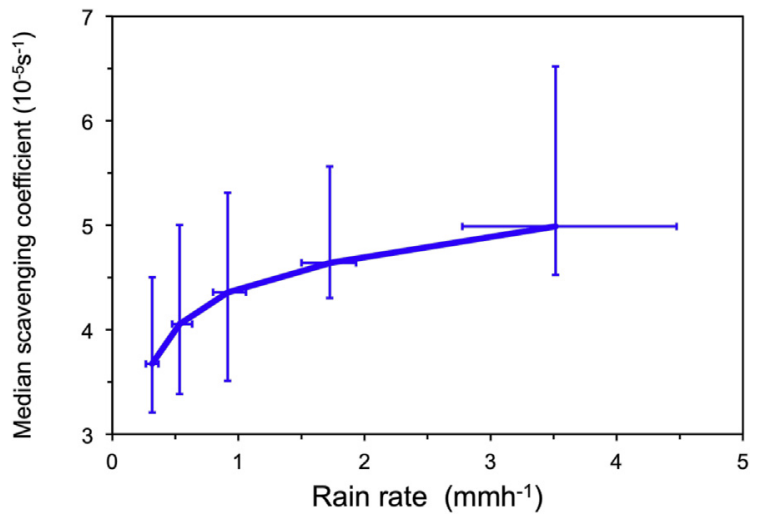

Fig. 11. Median sub-cloud scavenging coefficients, $\left(10^{-5} \mathrm{~s}^{-1}\right)$, taken at all three stations over the diameter range $10-800 \mathrm{~nm}$ in five classes of rain rate per event indicated by horizontal error bars. Vertical error bars indicate $25 \%$ and $75 \%$ percentiles of the scavenging coefficients.

here by far the highest number connected data hours were available, combined with relatively few aerosol sources on the path, (cf. Table 2), and favorable meteorological conditions, i.e. frequent precipitation along the path. The other two paths in regime two had far less numbers of connected hours and much less favorable meteorological conditions, i.e. there were only few precipitation events along the paths $\mathrm{ME} \rightarrow \mathrm{NG}$, and $\mathrm{ME} \rightarrow \mathrm{WA}$.

As in the case of inter-station particle growth a simple model is formulated to describe the PNSD at the end of the transport path at station B with the PNSD at the starting point, (station A). Simply applying the scavenging coefficients derived at the individual stations at precipitation events occurring between A and B was not sufficient to describe the connected results at station $\mathrm{B}$. As an example we show in Fig. 12 average PNSDs on the path WA $\rightarrow$ ME for 613 events of $\geq 1 \mathrm{~mm}$ precipitation during at least three transport hours. Just wet-scavenging PNSDs at station WA yielded much too low number concentrations at station ME. Even optimizing the level of the applied wet scavenging coefficients with Microsoft Excel's GRG-solver left substantial discrepancies between the scavenged WA-PNSD and the ME-PNSD, (cf. curve optimized WAscav in Fig. 12). Consequently, we had to assume some aerosol sources along the path, which we simulated with two lognormal distributions.

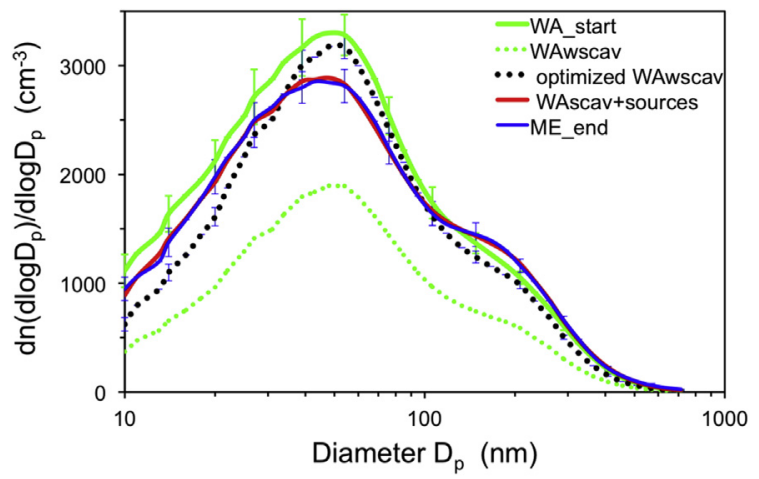

Fig. 12. Average particle number size distributions before, (WA_start, green), and after, (ME_end, blue), 613 transport events with precipitation $\geq 1 \mathrm{~mm}$ for at least three hours. The dotted green line indicates the potential size distribution at station ME if only wet scavenging of the starting aerosol had occurred. The dotted black line gives the optimized scavenged size distribution of station WA. The red line indicates the wet-scavenged size distribution of station WA augmented with two optimized lognormal distributions representing the aerosol sources along the transport. Vertical error bars show two standard deviations of the mean values. (For interpretation of the references to color in this figure legend, the reader is referred to the Web version of this article.)

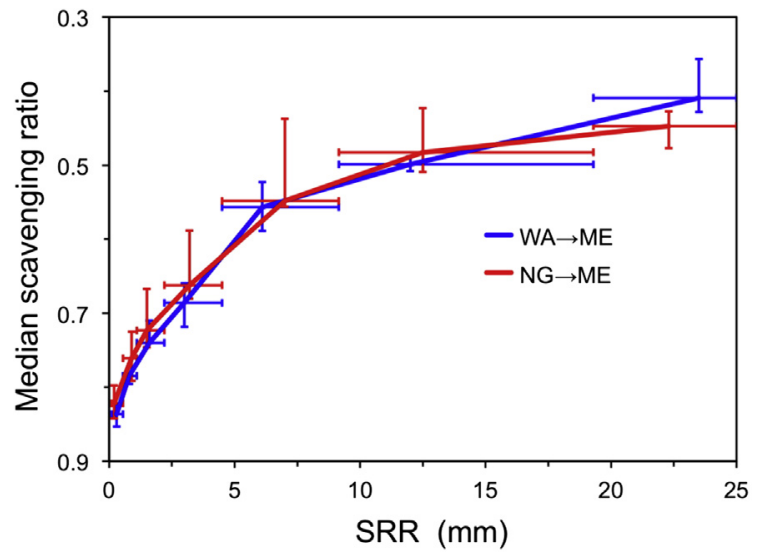

Fig. 13. Median sub-cloud scavenging ratios in seven classes of precipitation sums, (SRR, mm) indicated by horizontal error bars, along the transport path from Waldhof to Melpitz, WA $\rightarrow$ ME, and Neuglobsow to Melpitz, NG $\rightarrow$ ME. Vertical error bars indicate $25 \%$ and $75 \%$ percentiles of the scavenging ratios.

The six parameters of the two lognormal distributions were optimized with Microsoft Excel's GRG-solver so that their sum plus the subcloud scavenged data from station WA fit the data at station ME within a few percent. For the example in Fig. 12 the parameters were added to Table 2 .

Following, e.g., Tomasi et al. (2017), we defined a sub-cloud wet scavenging ratio as the concentration ratio of an air pollutant during or at the end of a precipitation event to its value before the event. This ratio describes the integral effect of precipitation after air mass transport between two stations. Accordingly, scavenging ratios were derived by subtracting the two lognormal distributions representing the on-path particle sources from the measured PNSD at station B and dividing the residuum by the un-scavenged results at station $\mathrm{A}$.

Median scavenging ratios were calculated over the central part of the size range of the particle spectrometers, $(20-200 \mathrm{~nm})$, and displayed in Fig. 13 as a function of precipitation sums along the transport paths WA $\rightarrow$ ME and NG $\rightarrow$ ME.

Over the range of 0.1 to $\approx 50 \mathrm{~mm}$ of precipitation along the transport path median scavenging ratios changed by a factor of $\approx 1.9$. Similar to the scavenging coefficients in Fig. 11 they planed out at higher rain sums. Within the $25 \%-75 \%$ percentiles the scavenging coefficients of the two transport paths agreed. Whereas in light precipitation, $(\leq 1 \mathrm{~mm})$ more than $80 \%$ of the initial aerosol particles in the considered range survived the transport over $\approx 200 \mathrm{~km}$ more than $50 \%$ was scavenged by more than $15 \mathrm{~mm}$ of precipitation during aerosol transport.

\section{Summary and conclusions}

The present study was based on hourly aerosol particle and ancillary data taken at three GUAN stations in Northeastern Germany $150-200 \mathrm{~km}$ apart in the years 2009 through 2015. The aim was to investigate systematic process related differences that might show up when connecting their data with forward and backward air mass trajectories. The analysis of aerosol changes during air mass transport between the stations focused on the two low-pollution-to-high-pollution pathways of similar distance around $200 \mathrm{~km}$ from Waldhof, (WA) to Melpitz, (ME) and Neuglobsow, (NG), to Melpitz. Despite rather different initial PNSDs the increases in total concentration of particle number, $(\triangle \mathrm{NTO})$, volume, $(\Delta \mathrm{VTO})$, and $\mathrm{BC},(\Delta \mathrm{BC})$, agreed within $15 \%$. Systematic variations were found in $\Delta \mathrm{NTO}, \Delta \mathrm{N} 26, \Delta \mathrm{VTO}$, and $\Delta \mathrm{BC}$ as a function of time of day at which an air mass transport from WA to ME took place that could be explained with related source and transport processes.

With Radar-based precipitation data at the stations and along the 
connecting trajectories sub-cloud particle scavenging was investigated at and in between the stations. At each station sub-cloud particle scavenging coefficients were determined as a function of particle size between 10 and $700 \mathrm{~nm}$ diameter, and as a function of precipitation sums. Median particle scavenging coefficients taken over the central part of the size range of the study strongly increased between 0.2 and $1 \mathrm{~mm}$ of precipitation and then planed out towards higher precipitation values. With the particle scavenging coefficients determined at the individual stations and precipitation data along connecting trajectories the sub-cloud particle scavenging analysis was extended to wet scavenging along the paths WA $\rightarrow \mathrm{ME}$, and NG $\rightarrow$ ME yielding median sub-cloud scavenging ratios over the range $0.2-25 \mathrm{~mm}$ of precipitation sums with a non-linear shape similar to that of the median particle scavenging coefficients at the individual stations. Whereas in light precipitation more than $80 \%$ of the initial particles in the considered range survived $150-200 \mathrm{~km}$ of transport, more than $50 \%$ was scavenged by more than $15 \mathrm{~mm}$ of precipitation during aerosol transport.

The present study used rather simplistic approaches to extrapolating aerosol data from a network of stations and to describe and quantify the effects of dry and wet aerosol processes between distant stations. It yielded new insights into processes leading to aerosol transformations. The accumulating GUAN data base however, offers much more than that with more detailed studies involving complex chemical/physical aerosol dynamics model such as presented by Tunved et al. (2010), for which the GUAN data base could be a test bed and with which more details of aerosol processes over the European region could be elucidated.

\section{Acknowledgements}

This work was accomplished in the framework of the project ACTRIS-2 (Aerosols, Clouds, and Trace gases Research InfraStructure) under the European Union-Research Infrastructure Action in the frame of the H2020 program for "Integrating and opening existing national and regional research infrastructures of European interest" under Grant Agreement N654109, (H2020-Horizon 2020). Additionally, we acknowledge the WCCAP (World Calibration Centre for Aerosol Physics) as part of the WMO-GAW program base-funded by the German Federal Environmental Agency (Umweltbundesamt). Continuous aerosol measurements at Melpitz were supported by the German Federal Environment Agency Grants F\&E 370343200 (German title: "Erfassung der Zahl feiner und ultrafeiner Partikel in der Außenluft"), and F\&E 371143232 (German title: "Trendanalysen gesundheitsgefährdender Fein-und Ultrafeinstaubfraktionen unter Nutzung der im German Ultrafine Aerosol Network (GUAN) ermittelten Immissionsdaten durch Fortführung und Interpretation der Messreihen"). We also thank Joachim Grüner and Dr. Gerald Spindler for their continuous technical support at the Melpitz station. We additionally thank the German Weather Service for providing Radolan RW data.

\section{References}

Asmi, A., Wiedensohler, A., Laj, P., Fjaeraa, A.M., Sellegri, K., Birmili, W., Weingartner, E., Baltensperger, U., Zdimal, V., Zikova, N., Putaud, J.P., Marinoni, A., Tunved, P., Hansson, H.C., Fiebig, M., Kivekäs, N., Lihavainen, H., Asmi, E., Ulevicius, V., Aalto, P.P., Swietlicki, E., Kristensson, A., Mihalopoulos, N., Kalivitis, N., Kalapov, I., Kiss, G., de Leeuw, G., Henzing, B., Harrison, R.M., Beddows, D., O'Dowd, C., Jennings, S.G., Flentje, H., Weinhold, K., Meinhardt, F., Ries, L., Kulmala, M., 2011. Number size distributions and seasonality of submicron particles in Europe 2008 - 2009. Atmos. Chem. Phys. 11, 5505-5538.

Baltensperger, U., Gäggeler, H.W., Jost, D.T., Lugauer, M., Schwikowski, M., Weingartner, E., Seibert, P., 1997. Aerosol climatology at the high-alpine site Jungfraujoch, Switzerland. J. Geophys. Res. 102, 19707-19715.

Bartels, H., Weigl, E., Reich, T., Lang, P., Wagner, A., Kohler, O., Gerlach, N., 2004. Projekt RADOLAN - Routineverfahren zur Online - Aneichung der Radarniederschlagsdaten mit Hilfe von Automatischen Bodenniederschlagsstationen (Ombrometer). Deutscher Wetterdienst, Offenbach, Germany.

Ben Bouallègue, Z., Theis, S.E., 2014. Spatial techniques applied to precipitation ensemble forecasts: from verification results to probabilistic products. Meteorol. Appl. 21, 922-929.

Birmili, W., Stratmann, F., Wiedensohler, A., 1999. Design of a DMA-based size spectrometer for a large particle size range and stable operation. J. Aerosol Sci. 30, 549-553.

Birmili, W., Sun, J., Weinhold, K., Merkel, M., Rasch, F., Wiedensohler, A., Bastian, S., Löschau, G., Schladitz, A., Quass, U., Kuhlbusch, T.A.J., Kaminski, H., Cyrys, J., Pitz, M., Gu, J., Kusch, T., Flentje, H., Meinhardt, F., Schwerin, A., Bath, O., Ries, L., Gerwig, H., Wirtz, K., Weber, S., 2015. Atmospheric aerosol measurements in the German Ultrafine Aerosol Network (GUAN) - Part 3: black Carbon mass and particle number concentrations 2009-2014. Gefahrst. Reinhalt. Luft 75, 479-488.

Birmili, W., Weinhold, K., Merkel, M., Rasch, F., Sonntag, A., Wiedensohler, A., Bastian, S., Schladitz, A., Löschau, G., Cyrys, J., Pitz, M., Gu, J., Kusch, T., Flentje, H., Quass, U., Kaminski, H., Kuhlbusch, T.A.J., Meinhardt, F., Schwerin, A., Bath, O., Ries, L., Wirtz, K., Fiebig, M., 2016. Long-term observations of tropospheric particle number size distributions and equivalent black carbon mass concentrations in the German Ultrafine Aerosol Network (GUAN). Earth Syst. Sci. Data 8, 355-382.

Birmili, W., Weinhold, K., Nordmann, S., Wiedensohler, A., Spindler, G., Müller, K., Herrmann, H., Gnauk, T., Pitz, M., Cyrys, J., Flentje, H., Nickel, C., Kuhlbusch, T.A.J., Löschau, G., Haase, D., Meinhardt, F., Schwerin, A., Ries, L., Wirtz, K., 2009. Atmospheric aerosol measurements in the German Ultrafine Aerosol Network (GUAN) - Part 1: soot and particle number size distributions. Gefahrst. Reinhalt. Luft 69, 137-145.

Birmili, W., Wiedensohler, A., Heintzenberg, J., Lehmann, K., 2001. Atmospheric particle number size distribution in Central Europe: statistical relations to air masses and meteorology. J. Geophys. Res. 106, 32005-32018.

Buzorius, G., Hämeri, K., Pekkanen, J., Kulmala, M., 1999. Spatial variation of aerosol number concentration in Helsinki city. Atmos. Environ. 33, 553-565.

Covert, D.S., Heintzenberg, J., 1984. Measurements of the degree of internal/external mixing of hygroscopic compounds and soot in atmospheric aerosols. Sci. Total Environ. 36, 347-352.

Dal Maso, M., Sogacheva, L., Aalto, P.P., Riipinen, I., Komppula, M., Tunved, P., Korhonen, L., Suur-Uski, V., Hirsikko, A., Kurtén, T., Kerminen, V.-M., Lihavainen, H., Viisanen, Y., Hansson, H.-C., Kulmala, M., 2007. Aerosol size distribution measurements at four Nordic field stations: identification, analysis and trajectory analysis of new particle formation bursts. Tellus 59B, 350-361.

Draxler, R., Rolph, G., 2003. HYSPLIT (HYbrid Single-particle Lagrangian Integrated Trajectory) Model Access via NOAA ARL READY. NOAA Air Resources Laboratory, Silver Spring, MD.

Eliassen, A., 1978. The OECD study of long range transport of air pollutants: long range transport modelling. Atmos. Environ. 12, 479-487.

Eliassen, A., Saltbones, J., 1983. Modelling of long-range transport of sulphur over Europe: a two-year model run and some model experiments. Atmos. Environ. 17, $1457-1473$.

Ellestad, T.G., 1980. Aerosol composition of urban plumes passing over a rural monitoring site. Ann. N. Y. Acad. Sci. 202-218.

Gao, Y., Zhao, C., Liu, X., Zhang, M., Leung, L.R., 2014. WRF-Chem simulations of aerosols and anthropogenic aerosol radiative forcing in East Asia. Atmos. Environ. 92, 250-266.

Gerstengarbe, F.-W., Werner, P.C., 1993. Katalog der Grosswetterlagen Europas nach Paul Hess und Helmut Brezowski 1881-1992. 4., vollständ. neu bearb. Aufl., Bericht des Deutschen Wetterdienstes. Deutscher Wetterdienst, Offenbach, Germany.

Größ, J., Hamed, A., Sonntag, A., Spindler, G., Manninen, H.E., Nieminen, T., Kulmala, M., Hõrrak, U., Plass-Dülmer, C., Wiedensohler, A., Birmili, W., 2018. Atmospheric new particle formation at the research station Melpitz, Germany: connection with gaseous precursors and meteorological parameters. Atmos. Chem. Phys. 18, $1835-1861$.

Hales, J.M., Berkowitz, C.M., Easter, R.C., 1988. Wet scavenging processes. In: van Dop, H. (Ed.), Air Pollution Modeling and It's Application. VI. Plenum Publishing Corporation, pp. 119-138.

Hallberg, A., Ogren, J.O., Noone, K.J., Okada, K., Heintzenberg, J., Svenningsson, I.B. 1994. The influence of aerosol particle composition on cloud droplet formation. J. Atmos. Chem. 19, 153-171.

Jiang, F., Liu, Q., Huang, X., Wang, T., Zhuang, B., Xie, M., 2012. Regional modeling of secondary organic aerosol over China using WRF/Chem. J. Aerosol Sci. 43, 57-73.

Johansson, C., Norman, M., Gidhagen, L., 2007. Spatial \& temporal variations of PM10 and particle number concentrations in urban air. Environ. Monit. Assess. 127, 477-478.

Kecorius, S., Kivekäs, N., Kristensson, A., Tuch, T., Covert, D.S., Birmili, W., Lihavainen, H., Hyvärinen, A.-P., Martinsson, J., Sporre, M.K., Swietlicki, E., Wiedensohler, A., Ulevicius, V., 2016. Significant increase of aerosol number concentrations in air masses crossing a densely trafficked sea area. Oceanologia 58, 1-12.

Kronenberg, R., Franke, J., Bernhofer, C., 2014. Comparison of different approaches to fit log-normal mixtures on radar-derived precipitation data. Meteorol. Appl. 21, 743-754.

Kulmala, M., Asmi, A., Lappalainen, H.K., Baltensperger, U., Brenguier, J.L., Facchini, M.C., Hansson, H.C., Hov, Ø., O'Dowd, C.D., Pöschl, U., Wiedensohler, A., Boers, R., Boucher, O., de Leeuw, G., Denier van der Gon, H.A.C., Feichter, J., Krejci, R., Laj, P., Lihavainen, H., Lohmann, U., McFiggans, G., Mentel, T., Pilinis, C., Riipinen, I., Schulz, M., Stohl, A., Swietlicki, E., Vignati, E., Alves, C., Amann, M., Ammann, M., Arabas, S., Artaxo, P., Baars, H., Beddows, D.C.S., Bergström, R., Beukes, J.P., Bilde, M., Burkhart, J.F., Canonaco, F., Clegg, S.L., Coe, H., Crumeyrolle, S., D'Anna, B., Decesari, S., Gilardoni, S., Fischer, M., Fjaeraa, A.M., Fountoukis, C., George, C., Gomes, L., Halloran, P., Hamburger, T., Harrison, R.M., Herrmann, H., Hoffmann, T., Hoose, C., Hu, M., Hyvärinen, A., Hõrrak, U., Iinuma, Y., Iversen, T., Josipovic, M., Kanakidou, M., Kiendler-Scharr, A., Kirkevåg, A., Kiss, G., Klimont, Z., Kolmonen, P., 
Komppula, M., Kristjánsson, J.E., Laakso, L., Laaksonen, A., Labonnote, L., Lanz, V.A., Lehtinen, K.E.J., Rizzo, L.V., Makkonen, R., Manninen, H.E., McMeeking, G., Merikanto, J., Minikin, A., Mirme, S., Morgan, W.T., Nemitz, E., O'Donnell, D., Panwar, T.S., Pawlowska, H., Petzold, A., Pienaar, J.J., Pio, C., Plass-Duelmer, C., Prévôt, A.S.H., Pryor, S., Reddington, C.L., Roberts, G., Rosenfeld, D., Schwarz, J. Seland, Ø., Sellegri, K., Shen, X.J., Shiraiwa, M., Siebert, H., Sierau, B., Simpson, D., Sun, J.Y., Topping, D., Tunved, P., Vaattovaara, P., Vakkari, V., Veefkind, J.P., Visschedijk, A., Vuollekoski, H., Vuolo, R., Wehner, B., Wildt, J., Woodward, S., Worsnop, D.R., van Zadelhoff, G.J., Zardini, A.A., Zhang, K., van Zyl, P.G., Kerminen, V.M., S Carslaw, K., Pandis, S.N., 2011. General overview: European Integrated project on Aerosol Cloud Climate and Air Quality interactions (EUCAARI): integrating aerosol research from nano to global scales. Atmos. Chem. Phys. 11, 13061-13143.

Laakso, L., Grönholm, T., Rannik, Ü., Kosmale, M., Fiedler, V., Vehkamäki, H., Kulmala, M., 2003. Ultrafine particle scavenging coefficients calculated from 6 years field measurements. Atmos. Environ. 37, 3605-3613.

Lammel, G., Engelhardt, T., Leip, A., Neusüß, C., Röhrl, A., Wehner, B., Wiedensohler, A., Wieser, P., 2005. Transformation of aerosol chemical properties due to transport over a city. J. Appl. Chem. 51, 95-117.

Latha, K.M., Badarinath, K.V.S., Reddy, P.M., 2005. Scavenging efficiency of rainfall on black carbon aerosols over an urban environment. Atmos. Sci. Lett. 6, 148-151.

Lemhaus, J., Saltbones, J., Eliassen, A., 1986. Calculated and Observed Data for 1980 Compared at EMEP Measurement Stations. The Norwegian Meteorological Institute EMEP/MSC-W Report 1/86, annex, Oslo, pp. 103.

Mäkelä, J.M., Koponen, I.K., Aalto, P., Kulmala, M., 2000. One-year data of submicron size modes of tropospheric background aerosol in southern Finland. J. Aerosol Sci. 31, 595-611.

Müller, T., Henzing, J.S., de Leeuw, G., Wiedensohler, A., Alastuey, A., Angelov, H., Bizjak, M., Collaud Coen, M., Engström, J.E., Gruening, C., Hillamo, R., Hoffer, A., Imre, K., Ivanow, P., Jennings, G., Sun, J.Y., Kalivitis, N., Karlsson, H., Komppula, M., Laj, P., Li, S.M., Lunder, C., Marinoni, A., Martins dos Santos, S., Moerman, M., Nowak, A., Ogren, J.A., Petzold, A., Pichon, J.M., Rodriquez, S., Sharma, S., Sheridan, P.J., Teinilä, K., Tuch, T., Viana, M., Virkkula, A., Weingartner, E., Wilhelm, R., Wang, Y.Q., 2011. Characterization and intercomparison of aerosol absorption photometers: result of two intercomparison workshops. Atmos. Meas. Tech. 4, 245-268.

Nordmann, S., Birmili, W., Weinhold, K., Wiedensohler, A., Mertes, S., Müller, K., Gnauk, T., Herrmann, H., Pitz, M., Cyrys, J., Flentje, H., Ries, L., Wirtz, K., 2009. Atmospheric aerosol measurements in the German Ultrafine Aerosol Network (GUAN) Part 2: comparison of measurements techniques for graphitic, light-absorbing, and elemental carbon, and non-volatile particle volume under field conditions. Gefahrst. Reinhalt. Luft 69, 469-474.

Petzold, A., Kramer, H., Schönlinner, M., 2002. Continuous measurement of atmospheric black carbon using a multi-angle absorption photometer. Environ. Sci. Pollut. Res. 4, $78-82$.

Petzold, A., Ogren, J.A., Fiebig, M., Laj, P., Li, S.M., Baltensperger, U., Holzer-Popp, T., Kinne, S., Pappalardo, G., Sugimoto, N., Wehrli, C., Wiedensohler, A., Zhang, X.Y., 2013. Recommendations for reporting "black carbon" measurements. Atmos. Chem. Phys. 13, 8365-8379.

Petzold, A., Schönlinner, M., 2004. Multi-Angle absorption photometry - a new method for the measurement of aerosol light absorption and atmospheric black carbon. J. Aerosol Sci. 35, 421-441.

Pfeifer, S., Birmili, W., Schladitz, A., Müller, T., Nowak, A., Wiedensohler, A., 2014. A fast and easy-to-implement inversion algorithm for mobility particle size spectrometers considering particle number size distribution information outside of the detection range. Atmos. Meas. Tech. 7, 95-105.

Qin, K., Wu, L., Wong, M.S., Letu, H., Hu, M., Lang, H., Sheng, S., Teng, J., Xiao, X., Yuan, L., 2016. Trans-boundary aerosol transport during a winter haze episode in China revealed by ground-based Lidar and CALIPSO satellite. Atmos. Environ. 141, 20-29. Sander, R., 2015. Compilation of Henry's law constants (version 4.0) for water as solvent.
Atmos. Chem. Phys. 15, 4399-4981.

Slinn, W.G.N., 1977. Some approximations for the wet and dry removal of particles andgases from the atmosphere. Water Air Soil Pollut. 7, 513-543.

Tomasi, C., Fuzzi, S., Kokhanovsky, A., 2017. Atmospheric Aerosols: Life Cycles and Effects on Air Quality and Climate. Wiley.

Tuch, T., Herbarth, O., Franck, U., Peters, A., Wehner, B., Wiedensohler, A., Heintzenberg, J., 2006. Weak correlation of ultrafine aerosol particle concentrations $<800 \mathrm{~nm}$ between two sites within one city. J. Expo. Anal. Environ. Epidemiol $16,486-490$.

Tunved, P., Hansson, H.-C., Kerminen, V.-M., Ström, J., Dal Maso, M., Lihavainen, H., Viisanen, Y., Aalto, P.P., Komppula, M., Kulmala, M., 2006a. High natural aeroso loading over boreal forests. Science 312, 261-263.

Tunved, P., Hansson, H.-C., Kulmala, M., Aalto, P., Viisanen, Y., Karlsson, H., Kristensson, A., Swietlicki, E., Dal Maso, M., Ström, J., Komppula, M., 2003. One year boundary layer aerosol size distribution data from five Nordic background stations. Atmos. Chem. Phys. 3, 2183-2205.

Tunved, P., Korhonen, H., Ström, J., Hansson, H.-C., Lehtinen, K.E.J., 2006b. Is nucleation capable of explaining observed aerosol integral number increase southerly transport over Scandinavia? Tellus B 58B, 129-140.

Tunved, P., Nilsson, E.D., Hansson, H.-C., Ström, J., Kulmala, M., Aalto, P., Viisanen, Y., 2005. Aerosol characteristics of air masses in northern Europe: influences of location, transport, sinks, and sources. J. Geophys. Res. 110, D07201 doi:07210.01029/ 02004JD005085.

Tunved, P., Partridge, D.G., Korhonen, H., 2010. New trajectory-driven aerosol and chemical process model Chemical and Aerosol Lagrangian Model (CALM). Atmos. Chem. Phys. 10, 10161-10185.

Väänänen, R., Kyrö, E.M., Nieminen, T., Kivekäs, N., Junninen, H., Virkkula, A., Dal Maso, M., Lihavainen, H., Viisanen, Y., Svenningsson, B., Holst, T., Arneth, A., Aalto, P.P., Kulmala, M., Kerminen, V.M., 2013. Analysis of particle size distribution changes between three measurement sites in northern Scandinavia. Atmos. Chem. Phys. 13, 11887-11903.

Vana, M., Kulmala, M., Dal Maso, M., Hörrak, U., Tamm, E., 2004. Comparative study of nucleation mode aerosol particles and intermediate air ions formation events at three sites. J. Geophys. Res. 109 (n/a).

Volken, M., Schumann, T., 1993. A critical review of below cloud aerosol scavenging results on Mt. Rigi. Water Air Soil Pollut. 68, 15-28.

Wehner, B., Siebert, H., Stratmann, F., Tuch, T., Wiedensohler, A., Petäjä, T., Dal Maso M., Kulmala, M., 2007. Horizontal homogeneity and vertical extent of new particle formation events. Tellus $59 \mathrm{~B}, 362-371$.

Weigl, E., Winterrath, T., 2009. Radargestützte Niederschlagsanalyse und -vorhersage (RADOLAN, RADVOR-OP). PRO 35, 78-86.

Wiedensohler, A., Birmili, W., Nowak, A., Sonntag, A., Weinhold, K., Merkel, M., Wehner, B., Tuch, T., Pfeifer, S., Fiebig, M., Fjäraa, A.M., Asmi, E., Sellegri, K., Depuy, R., Venzac, H., Villani, P., Laj, P., Aalto, P., Ogren, J.A., Swietlicki, E., Williams, P., Roldin, P., Quincey, P., Hüglin, C., Fierz-Schmidhauser, R., Gysel, M., Weingartner, E., Riccobono, F., Santos, S., Grüning, C., Faloon, K., Beddows, D., Harrison, R., Monahan, C., Jennings, S.G., O'Dowd, C.D., Marinoni, A., Horn, H.G., Keck, L., Jiang, J., Scheckman, J., McMurry, P.H., Deng, Z., Zhao, C.S., Moerman, M., Henzing, B., de Leeuw, G., Löschau, G., Bastian, S., 2012. Mobility particle size spectrometers: harmonization of technical standards and data structure to facilitate high quality longterm observations of atmospheric particle number size distributions. Atmos. Meas. Tech. 5, 657-685.

Wiedensohler, A., Wiesner, A., Weinhold, K., Birmili, W., Hermann, M., Merkel, M., Müller, T., Pfeifer, S., Schmidt, A., Tuch, T., Velarde, F., Quincey, P., Seeger, S. Nowak, A., 2017. Mobility particle size spectrometers: calibration procedures and measurement uncertainties. Aerosol Sci. Technol. 1-19.

Ye, X., Song, Y., Cai, X., Zhang, H., 2016. Study on the synoptic flow patterns and boundary layer process of the severe haze events over the North China Plain in January 2013. Atmos. Environ. 124, 129-145. 